\title{
EFFECT OF SODIUM SILICATE TO SODIUM HYDROXIDE RATIOS ON DURABILITY OF GEOPOLYMER MORTARS CONTAINING NATURAL AND ARTIFICIAL POZZOLANS
}

\author{
F. NURHAYAT DEGIRMENCI \\ Balikesir University, Architecture Faculty, Department of Architecture, Cagis Campus, 10145, Balikesir, Turkey \\ "E-mail: nurhayat@balikesir.edu.tr
}

Submitted May 14, 2017; accepted June 24, 2017

\begin{abstract}
Keywords: Fly ash, Ground granulated blast furnace slag, Natural zeolite, Geopolymer, Sulphate and acid resistance
This study aims to provide the experimental data on the sulphate and acid performance of geopolymer mortar containing pozzolanic materials such as fly ash (FA), ground granulated blast furnace slag (GGBS) and natural zeolite (NZ). The alkaline solution was the combination of sodium silicate and sodium hydroxide solution with the ratio $\left(\mathrm{Na}_{2} \mathrm{SiO}_{3} / \mathrm{NaOH}\right)$ of 1.0, 2.0 and 3.0. The molarity of sodium hydroxide was fixed as 10. The performances of geopolymer mortar were measured in terms of sodium and magnesium sulphate resistance and sulphuric and hydrochlorich acid resistance with $5 \%$ and $10 \%$ concentration after 24 weeks. The evaluations were measured as visual observation, measurement of weight change and residual compressive strength. It has been observed that $\mathrm{Na}_{2} \mathrm{SiO}_{3} / \mathrm{NaOH}$ ratio is effective on residual compressive strength of geopolymer mortar in both sulphate and acid exposure. The higher ratio of $\mathrm{Na}_{2} \mathrm{SiO}_{3} / \mathrm{NaOH}$ results in a higher residual compressive strength. The GGBS based geopolymer mortar has a very good resistance in acid media in terms of weight loss and residual compressive strength. The inclusion of FA in the GGBS based geopolymer mixture was found to be a suitable base of geopolymer mortar under ambient curing conditions.
\end{abstract}

INTRODUCTION

The durability of concrete is an important requirement for the performance in aggressive environments throughout its design life period. Sulphate attack is known to produce significant degradation in concrete structures. In hardened cement $\mathrm{C}_{3} \mathrm{~A}$ reacts with sulphate ions in the presence of calcium hydroxide to form ettringite and gypsum, leading to expansion and degradation of concrete [1]. Geopolymer is a new class of material generally manufactured by activating an aluminosilicate source material in a highly alkaline medium. Davidovits et al. [2] reported that geopolymer possesses high early strength, better durability and has no dangerous alkali-aggregate reaction. Geopolymers can be produced out of industrial by-products such as fly ash or slag, which are alkali activated and cured to produce a polymeric base gel [3-5]. The researchers concluded that the geopolymer concrete was proved to have better mechanical properties and better durability in aggressive environments as compared to conventional cement concrete [6-9]. Davidovits et al.[10] reported that geopolymers exposed to $5 \%$ sulphuric and hydrochloric acid were relatively stable with weight loss of in the range of $5-8 \%$ while the Portland based cements were destroyed and the calcium alumina cement lost weight about $30-60 \%$. Since geopolymers relies on alumina-silicate rather than calcium silicate hydrate it has been reported as being acid resistant. A large number of studies were conducted on geopolymer concrete, but there is still no consensus on the influence of different parameters on the properties of geopolymer materials. The main parameters which influence the properties of geopolymer concrete include aluminosilicate source, curing conditions, type and concentration of alkaline activator and the alkaline activator to base ratio [11-14]. $\mathrm{NaOH}$ and $\mathrm{Na}_{2} \mathrm{SiO}_{3}$ are commonly used to activate the fly ash in geopolymer concrete [15]. Previous studies have shown that the $\mathrm{Na}_{2} \mathrm{SiO}_{3} / \mathrm{NaOH}$ ratio and $\mathrm{NaOH}$ molarity affects the compressive strength of the geopolymer mortar [16]. The possible explanation of this increase may be connected to the use of more sodium silicate which led to more silica gel, and thus contributed to the high strength. Hardjito and Rangan [17] also claimed that a high ratio of $\mathrm{Na}_{2} \mathrm{SiO}_{3} / \mathrm{NaOH}$ by mass, results in high compressive strength. The $\mathrm{Na}_{2} \mathrm{SiO}_{3} / \mathrm{NaOH}$ ratio, by mass, was recommended at approximately 2.5 for fly ash-based geopolymers. Conversely, when the $\mathrm{Na}_{2} \mathrm{SiO}_{3} / \mathrm{NaOH}$ ratio was more than 3.0 , the compressive strength tended to decrease due to the excessive alkali content which retards the geopolymerisation reaction. According to various researches, $\mathrm{Na}_{2} \mathrm{SiO}_{3}$ favors the polymerization process leading to reaction product with more $\mathrm{Si}$ and higher mechanical strength [18]. The increase in compressive strength may be attributed to the increase in the $\mathrm{SiO}_{2}$ content of $\mathrm{Na}_{2} \mathrm{SiO}_{3}$ solution than the $\mathrm{NaOH}$ solution. Thokchom et al [19] investigated the effect of sodium oxide content on durability of geopolymer in 
sulphuric acid. The specimen with higher alkali content performed much better, than those with a lower alkali content in terms of residual compressive strength.

There are limited researches on the effect of sodium silicate to sodium hydroxide $\left(\mathrm{Na}_{2} \mathrm{SiO}_{3} / \mathrm{NaOH}\right)$ ratio on durability properties of geopolymer mortar especially for natural zeolite based mortar. The objective of the present experimental research is to provide experimental data on the effect of $\mathrm{Na}_{2} \mathrm{SiO}_{3} / \mathrm{NaOH}$ ratio of alkaline solution on durability performance of geopolymer mortar containing pozzolanic materials such as fly ash, ground granulated blast furnace slag and natural zeolite. The performances of geopolymer mortar were measured in terms of sodium and magnesium sulphate resistance and sulphuric and hydrochlorich acid resistance. The evaluations were done through visual observation, measurement of weight change and residual compressive strength. The geopolymer technology shows considerable promise for application in concrete industry as an alternative binder to the Portland cement. In terms of reducing the global warming, the geopolymer technology could reduce the $\mathrm{CO}_{2}$ emission to the atmosphere caused by cement and aggregates industries by about $80 \%$.

\section{EXPERIMENTAL}

Materials

Low-calcium (ASTM Class F) [20] fly ash, ground granulated blast furnace slag (GGBS) as a by-product of the steel industry conforming to TS EN 15167 [21] and natural zeolite-clinoptilolite (NZ) was used as base materials to produce geopolymer mortars in this study. The chemical composition and physical properties of FA, GGBS and NZ are shown in Tables 1 and 2, respectively. Silica sand graded similar to standard sand [22] was used as fine aggregate in production of geopolymer mortar.

Table 1. Chemical composition and physical properties of base materials used.

\begin{tabular}{|c|c|c|c|}
\hline \multirow[t]{2}{*}{ Notation } & FA & GGBS & $\mathrm{NZ}$ \\
\hline & \multicolumn{3}{|c|}{ Chemical composition $(\%)$} \\
\hline $\mathrm{SiO}_{2}$ & 52.90 & 41.67 & 68.30 \\
\hline $\mathrm{Al}_{2} \mathrm{O}_{3}$ & 25.50 & 11.56 & 10.97 \\
\hline $\mathrm{Fe}_{2} \mathrm{O}_{3}$ & 8.70 & 0.90 & 1.02 \\
\hline $\mathrm{CaO}$ & 4.75 & 35.58 & 3.24 \\
\hline $\mathrm{MgO}$ & 3.10 & 5.28 & 1.01 \\
\hline $\mathrm{Na}_{2} \mathrm{O}$ & 0.40 & 0.68 & 0.17 \\
\hline $\mathrm{K}_{2} \mathrm{O}$ & 2.00 & 1.00 & 2.40 \\
\hline $\mathrm{SO}_{3}$ & 2.90 & 0.10 & - \\
\hline $\mathrm{Cl}^{-}$ & 0.002 & 0.0105 & - \\
\hline FreeCaO & 0.88 & - & - \\
\hline Reactive $\mathrm{SiO}_{2}$ & 34.06 & - & 54.93 \\
\hline Reactive $\mathrm{CaO}$ & 0.60 & 82.53 & - \\
\hline \multirow[t]{2}{*}{ LOI } & 0.53 & 0.01 & 12.90 \\
\hline & \multicolumn{3}{|c|}{ Physical properties } \\
\hline Retained on $45 \mu \mathrm{m}(\%)$ & 25 & 0.5 & 20 \\
\hline Specific gravity $\left(\mathrm{g} \cdot \mathrm{cm}^{-3}\right)$ & 2.29 & 2.86 & 2.19 \\
\hline Blaine Surface area $\left(\mathrm{m}^{2} \cdot \mathrm{kg}^{-1}\right)$ & 380 & 465 & 129 \\
\hline \multicolumn{4}{|l|}{ Strength activity index (\%) } \\
\hline 7-days & 62 & 53 & 83 \\
\hline 28-days & 80 & 71 & 88 \\
\hline
\end{tabular}

Table 2. Mix proportions of geopolymer mortars.

\begin{tabular}{|c|c|c|c|c|c|c|c|c|c|c|c|}
\hline \multirow[t]{2}{*}{ Mix ID } & \multicolumn{2}{|c|}{ NZ } & \multicolumn{2}{|c|}{ FA } & \multicolumn{2}{|c|}{ GGBS } & \multirow{2}{*}{$\frac{\text { Sand }}{\mathrm{kg} \cdot \mathrm{m}^{-3}}$} & \multirow{2}{*}{$\begin{array}{c}\begin{array}{c}\text { Extra } \\
\text { water added }\end{array} \\
\mathrm{kg} \cdot \mathrm{m}^{-3}\end{array}$} & \multirow{2}{*}{$\begin{array}{l}\mathrm{Na}_{2} \mathrm{SiO}_{3} \\
\text { solution } \\
\mathrm{kg} \cdot \mathrm{m}^{-3}\end{array}$} & \multirow{2}{*}{$\frac{\mathrm{NaOH}}{\mathrm{kg} \cdot \mathrm{m}^{-3}}$} & \multirow{2}{*}{$\begin{array}{l}\mathrm{Na}_{2} \mathrm{SiO}_{3} \text {-to- } \mathrm{NaOH} \\
\text { ratio (by weight) }\end{array}$} \\
\hline & $\%$ & $\mathrm{~kg} \cdot \mathrm{m}^{-3}$ & $\%$ & $\mathrm{~kg} \cdot \mathrm{m}^{-3}$ & $\%$ & $\mathrm{~kg} \cdot \mathrm{m}^{-3}$ & & & & & \\
\hline $\mathrm{NZ}$ & 100 & 510 & - & - & - & - & 1530 & 80 & 127.5 & 127.5 & \multirow{6}{*}{1.0} \\
\hline FA & - & - & 100 & 510 & - & - & 1530 & 40 & 127.5 & 127.5 & \\
\hline GGBS & - & - & - & - & 100 & 510 & 1530 & - & 127.5 & 127.5 & \\
\hline $\mathrm{NZ}+\mathrm{FA}$ & 50 & 255 & 50 & 255 & - & - & 1530 & 40 & 127.5 & 127.5 & \\
\hline NZ+GGBS & 50 & 255 & - & - & 50 & 255 & 1530 & 40 & 127.5 & 127.5 & \\
\hline $\mathrm{FA}+\mathrm{GGBS}$ & - & - & 50 & 255 & 50 & 255 & 1530 & - & 127.5 & 127.5 & \\
\hline $\mathrm{NZ}$ & 100 & 510 & - & - & - & - & 1530 & 90 & 170 & 85 & \multirow{6}{*}{2.0} \\
\hline FA & - & - & 100 & 510 & - & - & 1530 & 40 & 170 & 85 & \\
\hline GGBS & - & - & - & - & 100 & 510 & 1530 & - & 170 & 85 & \\
\hline $\mathrm{NZ}+\mathrm{FA}$ & 50 & 255 & 50 & 255 & - & - & 1530 & 40 & 170 & 85 & \\
\hline NZ+GGBS & 50 & 255 & - & - & 50 & 255 & 1530 & 40 & 170 & 85 & \\
\hline $\mathrm{FA}+\mathrm{GGBS}$ & - & - & 50 & 255 & 50 & 255 & 1530 & - & 170 & 85 & \\
\hline $\mathrm{NZ}$ & 100 & 510 & - & - & - & - & 1530 & 90 & 191.25 & 63.75 & \multirow{6}{*}{3.0} \\
\hline FA & - & - & 100 & 510 & - & - & 1530 & 40 & 191.25 & 63.75 & \\
\hline GGBS & - & - & - & - & 100 & 510 & 1530 & 40 & 191.25 & 63.75 & \\
\hline $\mathrm{NZ}+\mathrm{FA}$ & 50 & 255 & 50 & 255 & - & - & 1530 & 20 & 191.25 & 63.75 & \\
\hline NZ+GGBS & 50 & 255 & - & - & 50 & 255 & 1530 & 20 & 191.25 & 63.75 & \\
\hline $\mathrm{FA}+\mathrm{GGBS}$ & - & - & 50 & 255 & - & 255 & 1530 & 20 & 191.25 & 63.75 & \\
\hline
\end{tabular}


The grading curve of used silica sand is presented in Figure 1 . In order to activate the base materials, commercial grade sodium hydroxide $(\mathrm{NaOH})$ and sodium silicate $\left(\mathrm{Na}_{2} \mathrm{SiO}_{3}\right)$ solutions were used as alkaline activator. The sodium silicate solution $\left(8 \% \mathrm{Na}_{2} \mathrm{O}, 27 \% \mathrm{SiO}_{2}\right.$ and $\left.65 \% \mathrm{H}_{2} \mathrm{O}\right)$ and sodium hydroxide $(\mathrm{NaOH})$ in flakes $98 \%$ purity were purchased from a local supplier in bulk. Distilled water was used to dissolve sodium hydroxide pellets to prevent any effect of unknown contaminants. Sodium hydroxide solution of required molarity and sodium silicate in liquid form were mixed and stored at room temperature of $23 \pm 2{ }^{\circ} \mathrm{C}$ and relative humidity $65 \%$ for $24 \mathrm{~h}$ before its use.

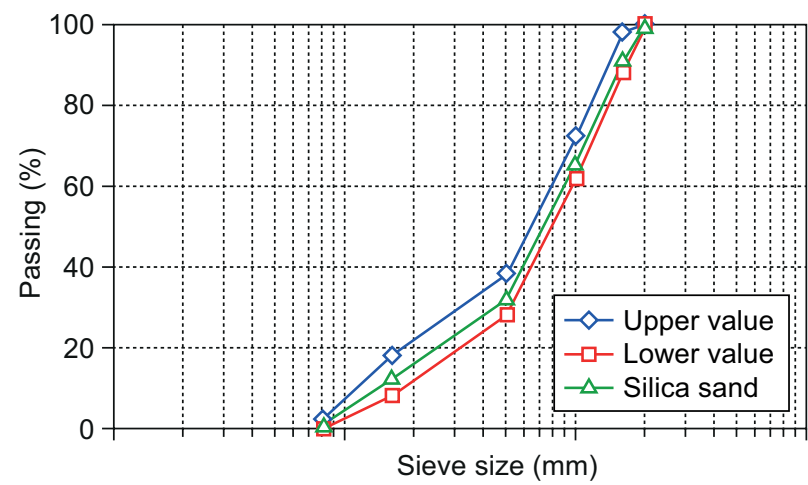

Figure 1. The grading curve of used silica sand.

\section{Preparation of geopolymer mortar specimens}

Geopolymer mortar can be produced by adopting the conventional techniques used in the manufacture of cement mortar. The weight ratio of sand to base material was fixed at 3.0 for all mixtures. Gopolymer mortars were prepared with a fixed alkali solution to base material ratio of 0.5. Extra water demand of mortar mixtures was determined with a standard flow table by flow diameter of $110 \pm 5 \mathrm{~mm}$ according to ASTM C230 [23] The mix proportions of geopolymer mortars are described in Table 2. The concentration of alkaline solution used was 10 molar. The ratios (by weight) of sodium silicate $\left(\mathrm{Na}_{2} \mathrm{SiO}_{3}\right)$ to sodium hydroxide $(\mathrm{NaOH})$ were 1,2 and 3. In the laboratory the base materials and sand were dry mixed in Hobart mixer for about three minutes. Then alkaline liquid was added along with extra water to maintain the workability of geopolymer mortars. The liquid component of the mixture was mixed for another five minutes. The mixing was carried out at room temperature at room temperature of $23 \pm 2{ }^{\circ} \mathrm{C}$. After the slump flow test, the fresh mortar was cast and compacted by the usual methods used in the case of cement mortar. The specimens were wrapped with plastic sheets to prevent from moisture loss. After 24 hours cured in the molds at room temperature, all mortar specimens were demoulded and cured at room temperature of $23 \pm 2^{\circ} \mathrm{C}$.

\section{Testing}

\section{Sulphate resistance}

Sulphate exposure testing procedure was conducted by immersing mortar specimens after the 28 days curing in a water tank containing $5 \%$ and $10 \%$ sodium sulphate and magnesium sulphate solutions for 24 weeks. The aggressive solutions were made by dissolving regent grade chemicals in tap water and test solutions were renewed every week. The test solution was kept in plastic containers with space between the mortar specimens at $23 \pm 2^{\circ} \mathrm{C}$ during the test period. Control mortar specimens were also immersed in the water during the same period and results were compared. Change in weight of specimens was measured after selected periods of exposure up to 24 weeks. On the day the weight was measured, the specimens were removed from the sulphate solution, and wiped clean prior to the measurement. The weight change of mortar specimens were measured until 24 weeks of exposure. The specimens were returned to the sulphate solution container immediately after the measurement was done. Average values were calculated from the measurements of three replicates.

\section{Acid resistance}

Acid resistance of geopolymer mortar was studied by immersing mortar specimens in $5 \%$ and $10 \%$ concentrations of acid solution up to 24 weeks and by evaluating the behaviour in terms of visual appearance, change in weight and change in compressive strength after exposure. The resistance to acid attack was determined in accordance with ASTM C-267[24]. The $50 \times$ $\times 50 \times 50 \mathrm{~mm}$ geopolymer mortar specimens were prepared and cured at room temperature. Three specimen of each mortar mixture immersed either in $5 \%$ and $10 \%$ sulphuric acid $\left(\mathrm{H}_{2} \mathrm{SO}_{4}\right)$ or in $5 \%$ and $10 \%$ hydrochloric acid $(\mathrm{HCl})$. After being subject to acid attack, the mortar specimens were cleaned with water and then the acid attack evaluated through measurement of the weight loss of the specimens. In order to maintain the concentration, the solution was replaced every week. For comparison, control specimens were soaked in tap water in the laboratory ambient conditions. All specimens were room temperature-cured at $23 \pm 2{ }^{\circ} \mathrm{C}$. The residual compressive strength evolution of geopolymer mortar was calculated as percentage of initial compressive strength.

\section{RESULTS AND DISCUSSION}

\section{Visual appearance}

The visual appearances of the test specimens after different exposures are shown in Figure 2-6. It can be seen that the visual appearance of the test specimens after soaking in sulphate solutions up to 24 weeks revealed that there was no change in the appearance of 


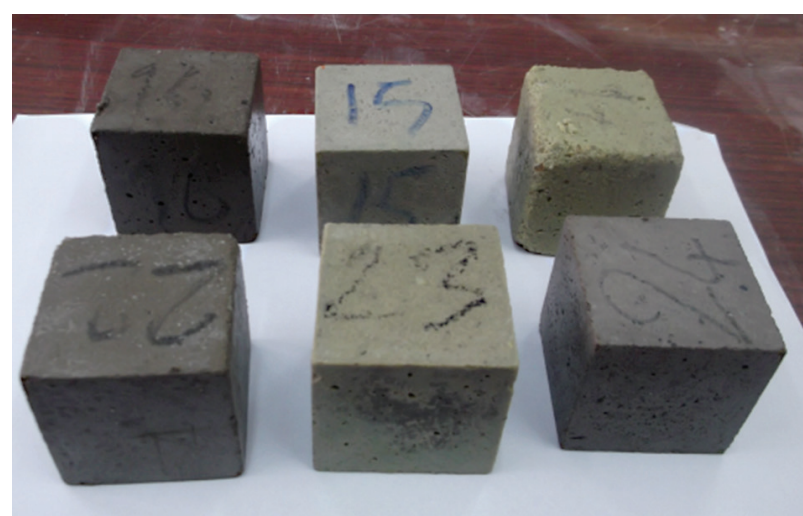

a) $5 \% \mathrm{Na}_{2} \mathrm{SO}_{4}$ solution

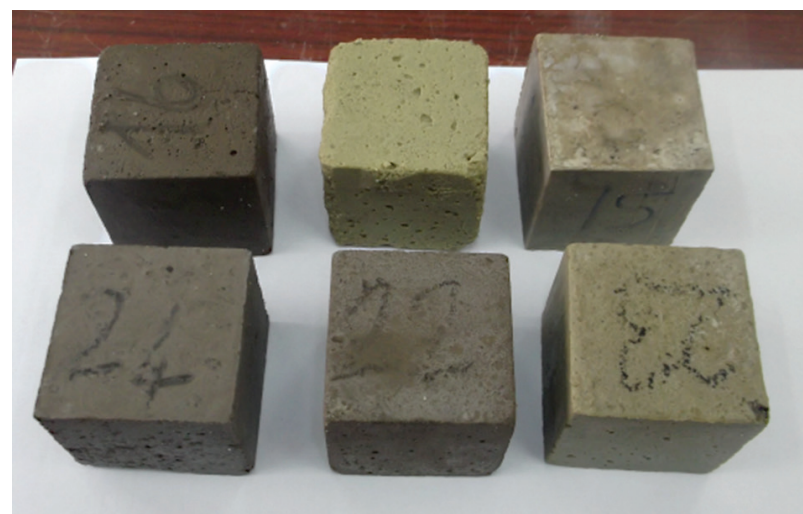

b) $10 \% \mathrm{Na}_{2} \mathrm{SO}_{4}$ solution

Figure 2. Visual appearance of geopolymer mortar specimens after 24 weeks exposure in: a) $5 \%$ and b) $10 \% \mathrm{Na}_{2} \mathrm{SO}_{4}$ solution.

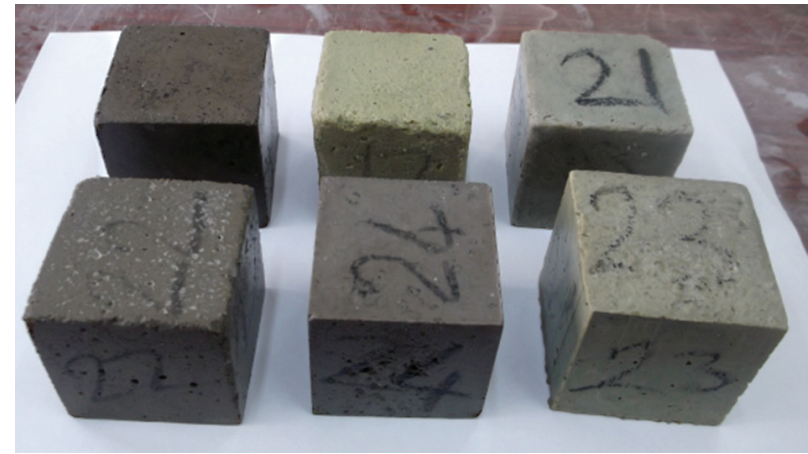

a) $5 \% \mathrm{MgSO}_{4}$ solution

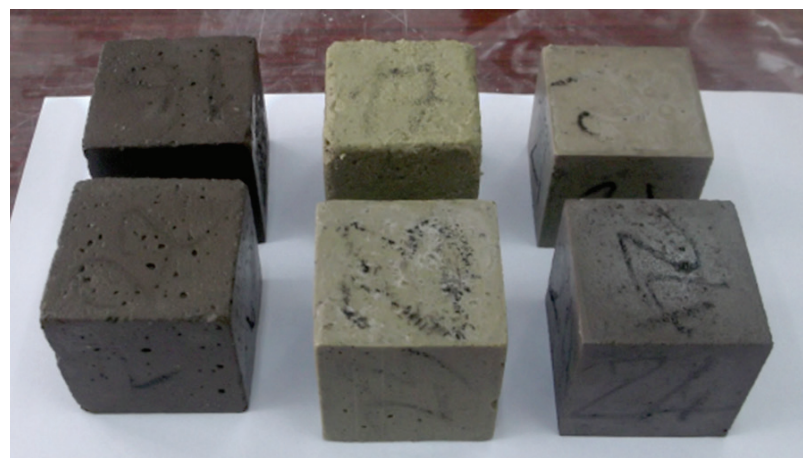

b) $10 \% \mathrm{MgSO}_{4}$ solution

Figure 3. Visual appearance of geopolymer mortar specimens after 24 weeks exposure in: a) $5 \%$ and b) $10 \% \mathrm{MgSO}_{4}$ solution.

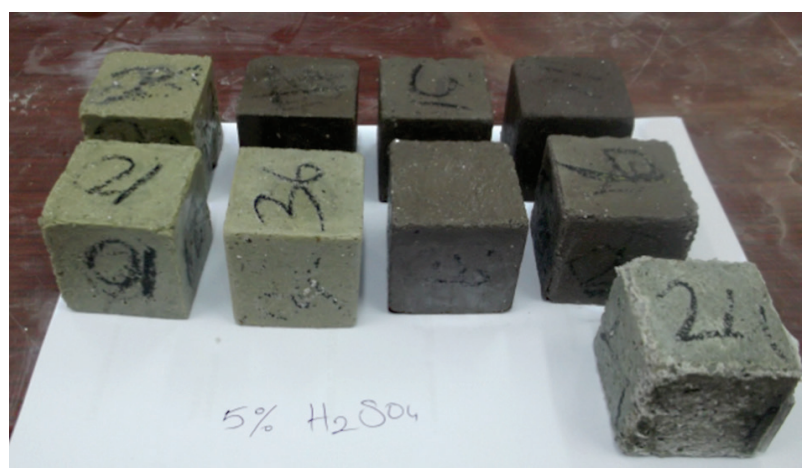

a) $5 \% \mathrm{H}_{2} \mathrm{SO}_{4}$ solution

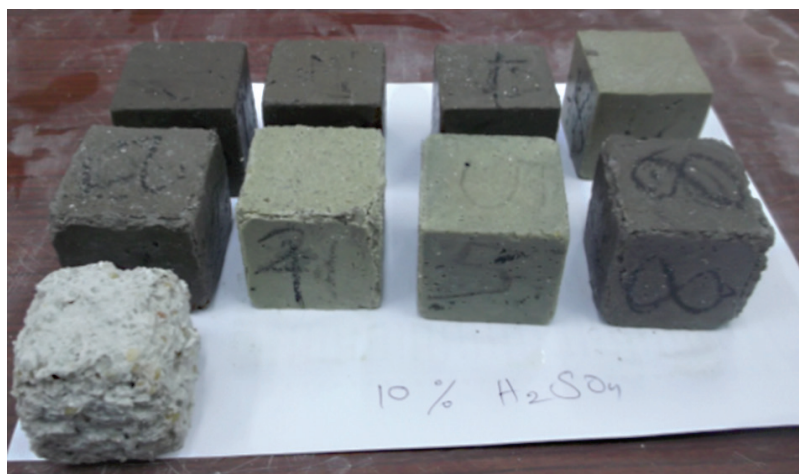

b) $10 \% \mathrm{H}_{2} \mathrm{SO}_{4}$ solution

Figure 4. Visual appearance of geopolymer mortar specimens after 24 weeks exposure in: a) $5 \%$ and b) $10 \% \mathrm{H}_{2} \mathrm{SO}_{4}$ solution.

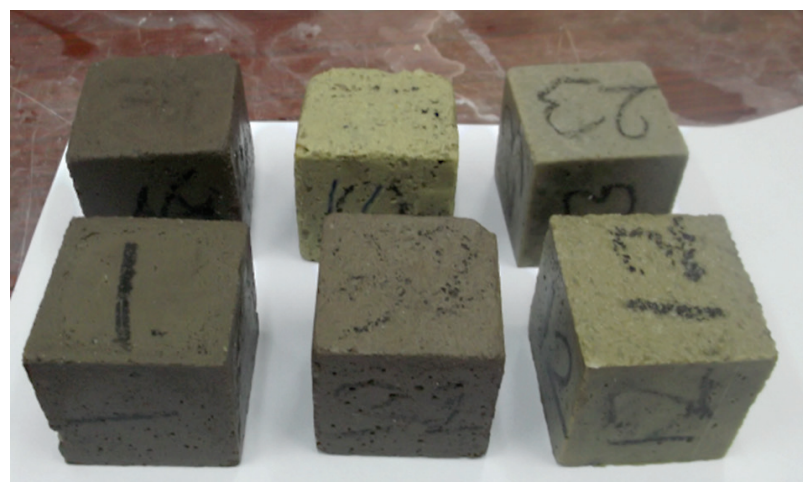

a) $5 \% \mathrm{HCl}$ solution

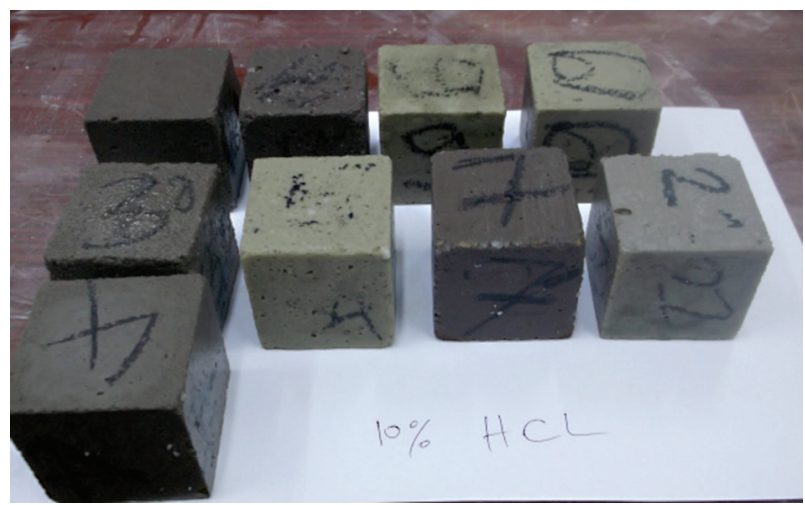

b) $10 \% \mathrm{HCl}$ solution

Figure 5. Visual appearance of geopolymer mortar specimens after 24 weeks exposure in: a) $5 \%$ and b) $10 \% \mathrm{HCl}$ solution. 
the specimens compared to the condition before they were exposed. There was no significant damage to the surface of test specimens after exposure to sodium and magnesium sulphate solution up to 6 months. The surface became a little softer as the duration of the test progressed but could not be easily scratched with finger nails. Bhutta et al. [25] also found that there was no significant damage to the surface of test specimens after exposure to $5 \%$ sodium sulphate solution up to one year. The geopolymer mortars were less susceptible to the attack by $5 \%$ magnesium sulphate solution. Figure 4 shows the visual appearance of the geopolymer mortar specimens after soaking in sulphuric acid solution for a period of 24 weeks. The specimens seemed to be slightly damaged at the surface and around the edges of specimens. In particular, it was observed that the surface of the NZ specimens exposed to $10 \%$ sulphuric acid was badly defeated and the aggregates were clearly visible (Figure 6). Other geopolymer spcimens compared to NZ specimens have suffered less damage in sulphuric acid solution. GGBS based specimens showed the best

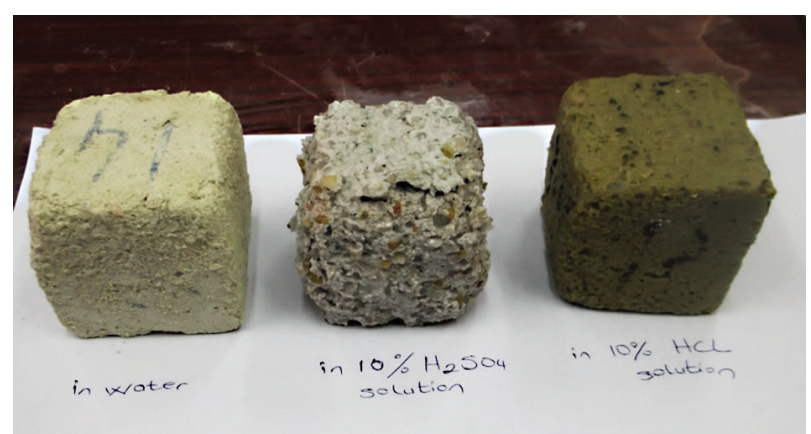

Figure 6. Visual appearance NZ specimens in water, $10 \%$ $\mathrm{H}_{2} \mathrm{SO}_{4}$ and $10 \% \mathrm{HCl}$ after 24 weeks of exposure. performance in sulphuric acid resistance, followed by FA based specimens in terms of performance of sulphuric acid. As can be seen from Figure 5, the specimens exposed to hydrochlorich acid solution have similiar appearances with sign of slight deterioration. Even in the $10 \%$ hydrochloric acid solution, the geopolymer samples were not much damaged compared to the samples exposed to sulphuric acid. The damage to the surface of the specimens increased as the concentration of the acid solution.

\section{Weight change}

The weight changes of geopolymer mortar specimens in sulphate solution are presented in Figure 7 and 8. The weight of all specimens was gradually increased within the exposure period up to 24 weeks in sulphate solution due to absorption of the exposed liquid. Rapid increase in weight occurred for all specimens up to 4 weeks of exposure and after 20 weeks, a decreasing trend was observed for all specimens. Maximum increase in weight was observed in NZ specimens and least gain in weight occurred in GGBS specimens. After 24 weeks NZ specimens slowly gained the weight of $6.94 \%, 6.54 \%$ and $6.14 \%$ for $\mathrm{Na}_{2} \mathrm{SiO}_{3} / \mathrm{NaOH}: 1.0$, $\mathrm{Na}_{2} \mathrm{SiO}_{3} / \mathrm{NaOH}: 2.0$ and $\mathrm{Na}_{2} \mathrm{SiO}_{3} / \mathrm{NaOH}: 3.0$, respectively in $10 \% \mathrm{Na}_{2} \mathrm{SO}_{4}$ solution. GGBS specimens gained the weight of $1.23 \%, 1.02 \%$ and $0.99 \%$ for $\mathrm{Na}_{2} \mathrm{SiO}_{3} /$ /NaOH:1.0, $\mathrm{Na}_{2} \mathrm{SiO}_{3} / \mathrm{NaOH}: 2.0$ and $\mathrm{Na}_{2} \mathrm{SiO}_{3} / \mathrm{NaOH}: 3.0$, respectively in $10 \% \mathrm{Na}_{2} \mathrm{SO}_{4}$ solution. $\mathrm{NZ}$ specimens gained the weight of $5.67 \%, 4.98 \%$ and $4.66 \%$ for $\mathrm{Na}_{2} \mathrm{SiO}_{3} / \mathrm{NaOH}: 1.0, \mathrm{Na}_{2} \mathrm{SiO}_{3} / \mathrm{NaOH}: 2.0$ and $\mathrm{Na}_{2} \mathrm{SiO}_{3} /$ $/ \mathrm{NaOH}: 3.0$, respectively in $10 \% \mathrm{MgSO}_{4}$ solution after 24 weeks. The results showed that NZ based geopolymer mortar specimens had gained weight to $6.26 \%$ and

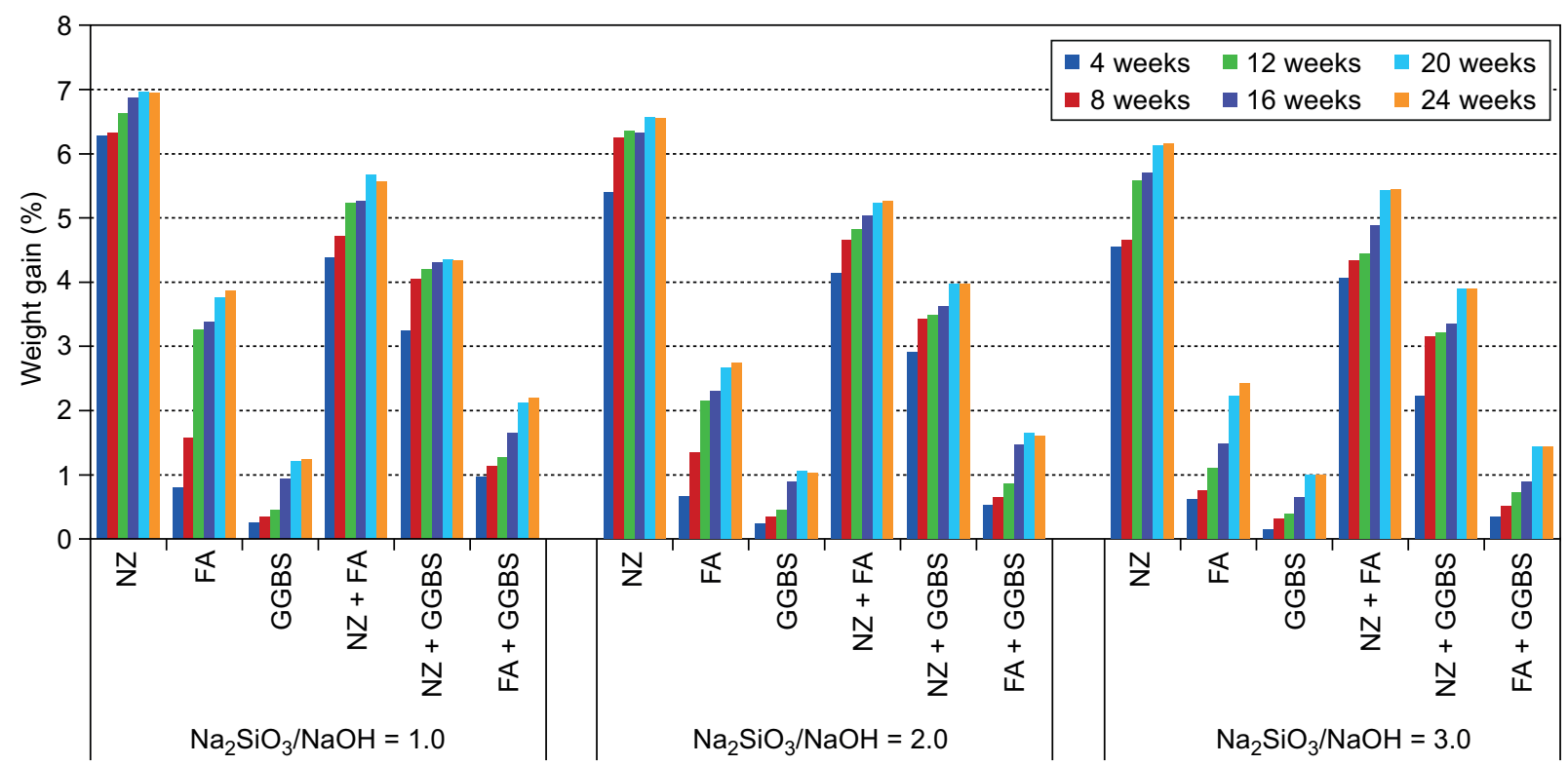

Figure 7. Effect of $\mathrm{Na}_{2} \mathrm{SiO}_{3} / \mathrm{NaOH}$ ratio in the alkaline solution and exposure period on weight gain of geopolymer mortars exposure to $10 \% \mathrm{Na}_{2} \mathrm{SO}_{4}$ solution. 
$4.09 \%$ in first month of exposure in sodium sulphate and magnesium sulphate solution, respectively. The increase in weight might be due to white deposits within the surface pores. These deposits were flaky or needle like during the early stages of exposure. The $\mathrm{Na}_{2} \mathrm{SiO}_{3} /$ $\mathrm{NaOH}$ ratio has effective on weight gain of geopolymer mortars. The gain of specimen weight when immersed in sodium and magnesium sulphate depends of the $\mathrm{Na}_{2} \mathrm{SiO}_{3} /$ $\mathrm{NaOH}$ ratios. The pattern of weight gain is almost similar in three different $\mathrm{Na}_{2} \mathrm{SiO}_{3} / \mathrm{NaOH}$ ratios. The maximum weight gain was produced by specimen with minimum $\mathrm{Na}_{2} \mathrm{SiO}_{3} / \mathrm{NaOH}$ ratio. On the other hand, the specimens immersed in acid solution, a sudden loss of weight was noticed initially during 4 to 12 weeks. Figure 9 represents the weight change of specimens exposed to sulphuric acid. After 24 weeks exposure period the weight of geopolymer specimens had gradually decreased with an increase in concentration and exposure period. Beyond 12 weeks the weight dropped in the specimens. Weight change is the most important criteria to investigate the effect of specimens after being exposed to sulphuric acid. The weight loss at the end of 24 weeks was found to be $17.53 \%$ for NZ specimens and $3.67 \%$ for GGBS specimens for $\mathrm{Na}_{2} \mathrm{SiO}_{3} / \mathrm{NaOH}: 1.0$ ratio. These values were as $6.89 \%$ for NZ specimens and $2.36 \%$ for GGBS specimens for $\mathrm{Na}_{2} \mathrm{SiO}_{3} / \mathrm{NaOH}: 3.0$ ratio. Geopolymer

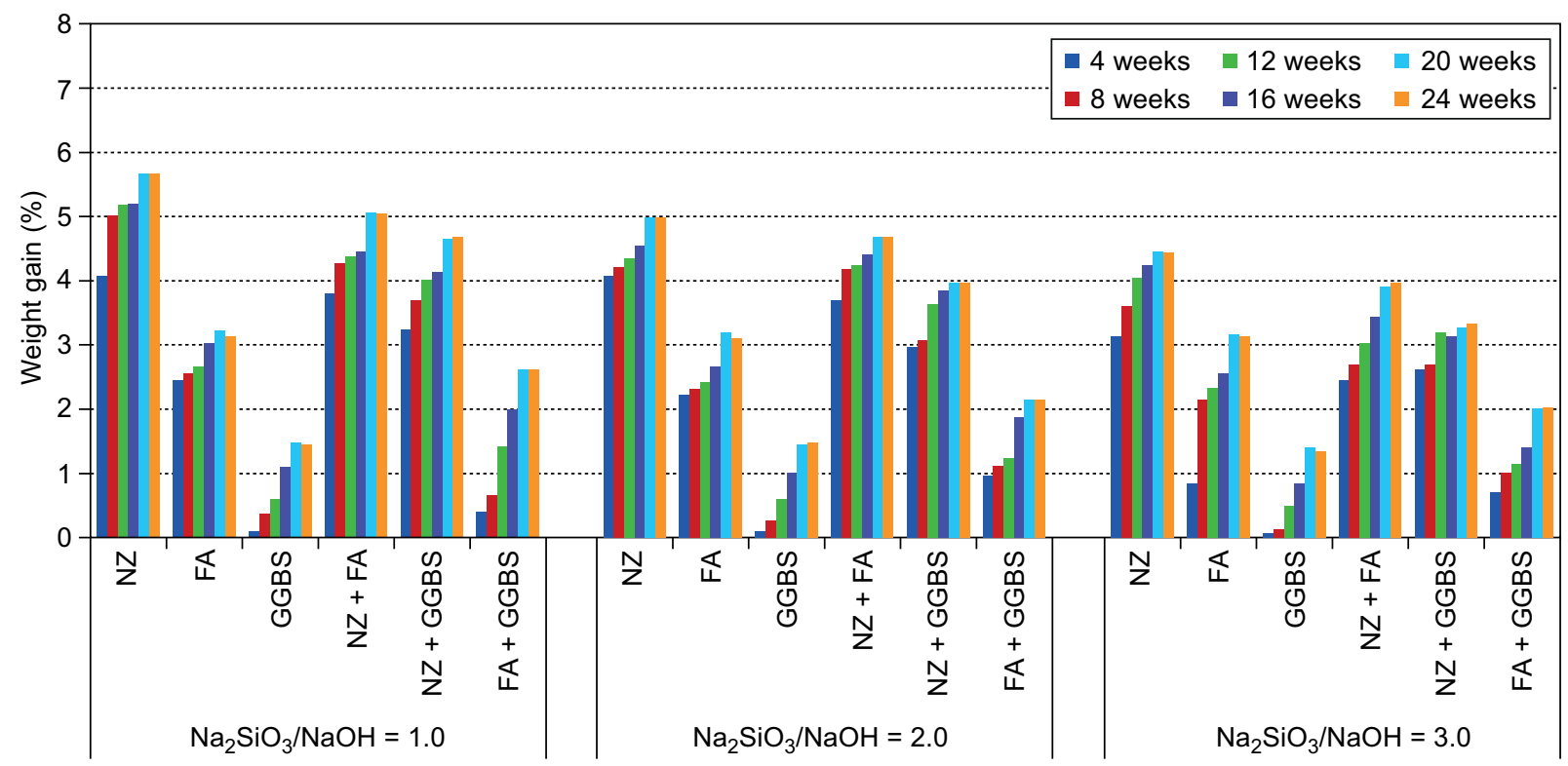

Figure 8. Effect of $\mathrm{Na}_{2} \mathrm{SiO}_{3} / \mathrm{NaOH}$ ratio in the alkaline solution and exposure period on weight gain of geopolymer mortars exposure to $10 \% \mathrm{MgSO}_{4}$ solution.

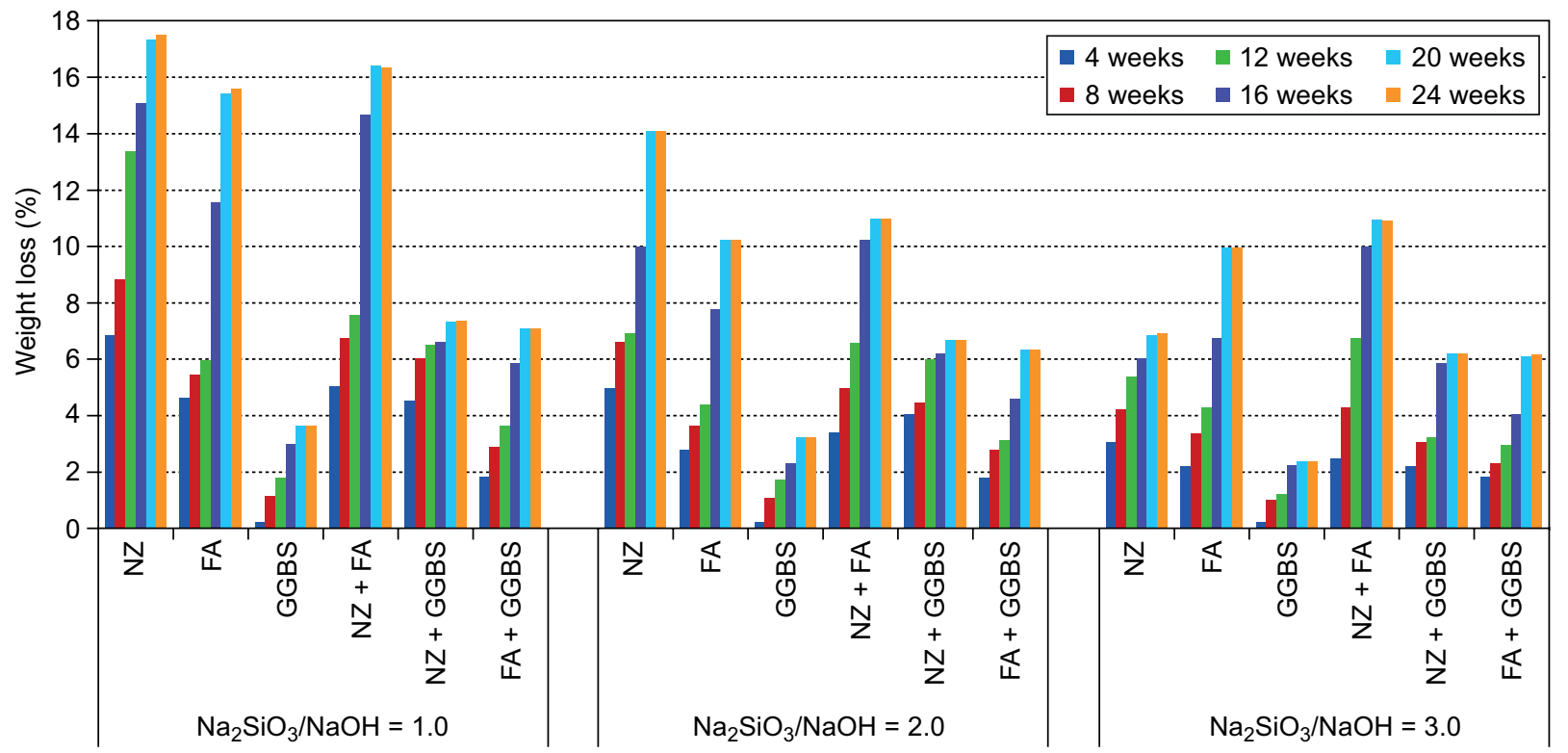

Figure 9. Effect of $\mathrm{Na}_{2} \mathrm{SiO}_{3} / \mathrm{NaOH}$ ratio in the alkaline solution and exposure period on weight loss of geopolymer mortars exposure to $10 \% \mathrm{H}_{2} \mathrm{SO}_{4}$ solution. 
specimens with the highest $\mathrm{Na}_{2} \mathrm{SiO}_{3} / \mathrm{NaOH}$ ratio had the minimum weight loss after 24 weeks. As the $\mathrm{Na}_{2} \mathrm{SiO}_{3} /$ $/ \mathrm{NaOH}$ ratio decreased in the specimens, weight loss also increased correspondingly in acid solution. Davidovits [1] found that geopolymer cements have very low weight loss of $5-8 \%$ when samples were immersed in $5 \%$ sulphuric acid and hydrochloric acid solutions. In contrast, Portland cements were completely destroyed in the same environment. The effect of $\mathrm{Na}_{2} \mathrm{SiO}_{3} / \mathrm{NaOH}$ ratio in the alkaline solution and exposure period on the weight loss of geopolymer mortars exposure to $10 \%$ $\mathrm{HCl}$ solution is presented in Figure 10. The weight loss of NZ specimens was $14.34 \%, 9.48 \%$ and $6.55 \%$ for $\mathrm{Na}_{2} \mathrm{SiO}_{3} / \mathrm{NaOH}: 1.0, \mathrm{Na}_{2} \mathrm{SiO}_{3} / \mathrm{NaOH}: 2.0$ and $\mathrm{Na}_{2} \mathrm{SiO}_{3} /$ $/ \mathrm{NaOH}: 3.0$, respectively in $10 \% \mathrm{HCL}$ solution after 24 weeks. The minimum weight losses were obtained in GGBS based samples while the maximum weight losss were obtained in NZ based specimens. Pacheco-Torgal and Jalali [26] mentioned an average weight loss of just $2.6 \%$ after being submitted to the attack of (sulphuric, hydrochloric and nitric) acids during 28 days, while the weight loss for Portland cement concretes is more than twice that value.

\section{Residual compressive strength}

The effect of $\mathrm{Na}_{2} \mathrm{SiO}_{3} / \mathrm{NaOH}$ ratio by weight on the resigual compressive strength of geopolymer mortar can be seen in Figure 11 and 12. Figure 11 represents the variation of residual compressive strength of geopolymer mortar specimens exposed to sodium and magnesium sulphate solution. After 24 weeks of exposure, all the specimens exhibited a decrease in residual compressive strength. Test results showed that the loss of compressive strength of geopolymer mortar decreases when the $\mathrm{Na}_{2} \mathrm{SiO}_{3} / \mathrm{NaOH}$ ratio increases. For three $\mathrm{Na}_{2} \mathrm{SiO}_{3} / \mathrm{NaOH}$ ratios, NZ specimens have the lowest residual compressive strength, while GGBS specimens have the highest residual compressive strength in sulphate exposure. The residual compressive strengths of NZ specimens were $26.32 \%$ and $24.31 \%$ in $5 \% \mathrm{Na}_{2} \mathrm{SO}_{4}$ and $10 \% \mathrm{Na}_{2} \mathrm{SO}_{4}$ solution and $29.06 \%$ and $28.13 \%$ in $5 \% \mathrm{MgSO}_{4}$ and $10 \% \mathrm{MgSO}_{4}$ respectively, for $\mathrm{Na}_{2} \mathrm{SiO}_{3} / \mathrm{NaOH}: 3.0$. The residual compressive strengths of GGBS specimens were $94.33 \%$ and 87.11 $\%$ in $5 \% \mathrm{Na}_{2} \mathrm{SO}_{4}$ and $10 \% \mathrm{Na}_{2} \mathrm{SO}_{4}$ solution and $100 \%$ in both $5 \%$ and $10 \% \mathrm{MgSO}_{4}$ respectively, for $\mathrm{Na}_{2} \mathrm{SiO}_{3} /$ $\mathrm{NaOH}: 3.0$. It was observed that high calcium presented in the base material makes the main geopolymerization products less susceptible to sulphate attack. As shown in Figure 12 exposure to acid caused degradation on compressive strength, extend of degradation depended on the concentration of acid solution. NZ specimens have the least residual compressive strength values for three $\mathrm{Na}_{2} \mathrm{SiO}_{3} / \mathrm{NaOH}$ ratios. The residual compressive strengths of $\mathrm{NZ}$ specimens were $38.73 \%, 42.29 \%$ and $48.11 \%$ for $\mathrm{Na}_{2} \mathrm{SiO}_{3} / \mathrm{NaOH}: 1.0, \mathrm{Na}_{2} \mathrm{SiO}_{3} / \mathrm{NaOH}: 2.0$ and $\mathrm{Na}_{2} \mathrm{SiO}_{3} / \mathrm{NaOH}: 3.0$, respectively in $5 \% \mathrm{H}_{2} \mathrm{SO}_{4}$. These values were $18.03 \%, 21.06 \%$ and $22.62 \%$ for $\mathrm{Na}_{2} \mathrm{SiO}_{3} /$ $/ \mathrm{NaOH}: 1.0, \mathrm{Na}_{2} \mathrm{SiO}_{3} / \mathrm{NaOH}: 2.0$ and $\mathrm{Na}_{2} \mathrm{SiO}_{3} / \mathrm{NaOH}: 3.0$, respectively in $10 \% \mathrm{H}_{2} \mathrm{SO}_{4}$. Among geopolymer mortars, GGBS specimens performed significantly better than the others. Next in performance was FA specimens which had a slow strength loss about after 24 weeks of exposure. The residual compressive strengths of GGBS specimens when exposed to $10 \% \mathrm{H}_{2} \mathrm{SO}_{4}$ were $61.73 \%, 66.82 \%$ and $71.42 \%$ for $\mathrm{Na}_{2} \mathrm{SiO}_{3} / \mathrm{NaOH}: 1.0, \mathrm{Na}_{2} \mathrm{SiO}_{3} / \mathrm{NaOH}: 2.0$ and $\mathrm{Na}_{2} \mathrm{SiO}_{3} / \mathrm{NaOH}: 3.0$, respectively. These strength

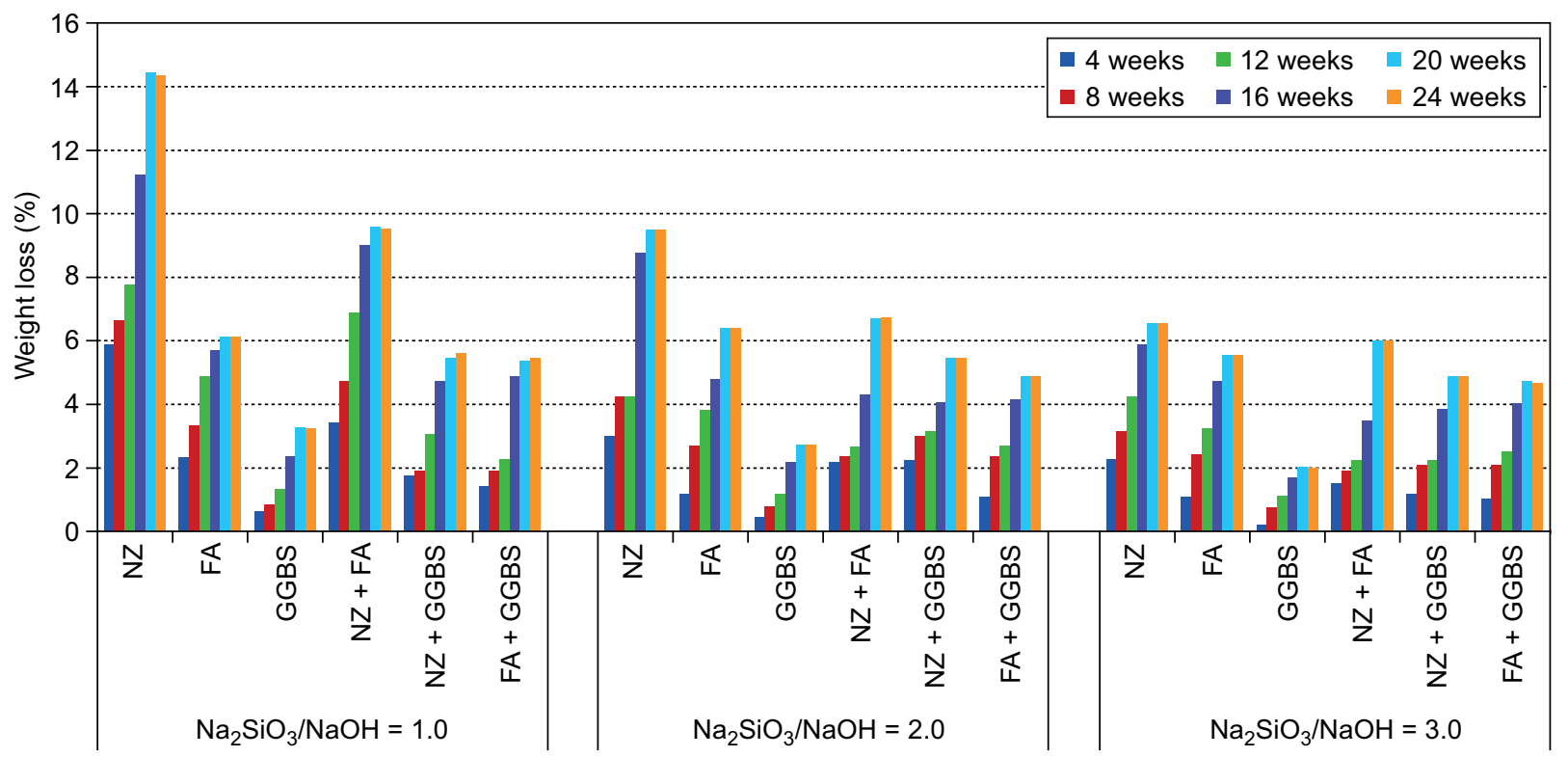

Figure 10. Effect of $\mathrm{Na}_{2} \mathrm{SiO}_{3} / \mathrm{NaOH}$ ratio in the alkaline solution and exposure period on weight loss of geopolymer mortars exposure to $10 \% \mathrm{HCl}$ solution. 
values were $53.59 \%, 55.62 \%$ and $58.13 \%$ for $\mathrm{Na}_{2} \mathrm{SiO}_{3} /$ $/ \mathrm{NaOH}: 1.0, \mathrm{Na}_{2} \mathrm{SiO}_{3} / \mathrm{NaOH}: 2.0$ and $\mathrm{Na}_{2} \mathrm{SiO}_{3} / \mathrm{NaOH}: 3.0$, respectively in Figure 12 also shows the evolution of the compressive strength of the specimens exposed to the hydrochloric acid solution. In contrast exposure in sulphuric acid, the geopolymer specimens had least strength loss in hydrochloric acid exposure. Geopolymer mortar specimens experienced loss in strength which was highest in the specimen manufactured with minimum $\mathrm{Na}_{2} \mathrm{SiO}_{3} / \mathrm{NaOH}$ ratio. However even after 24 weeks in $10 \%$ hydrochloric acid the least residual compressive strength measured was $43.06 \%$ for NZ specimens for $\mathrm{Na}_{2} \mathrm{SiO}_{3} / \mathrm{NaOH}: 1.0$ ratio. GGBS specimens have the highest residual compressive strength as $58.13 \%$ and $82.36 \%$ in exposure of $10 \%$ sulphuric and hydrochloric acid, respectively.

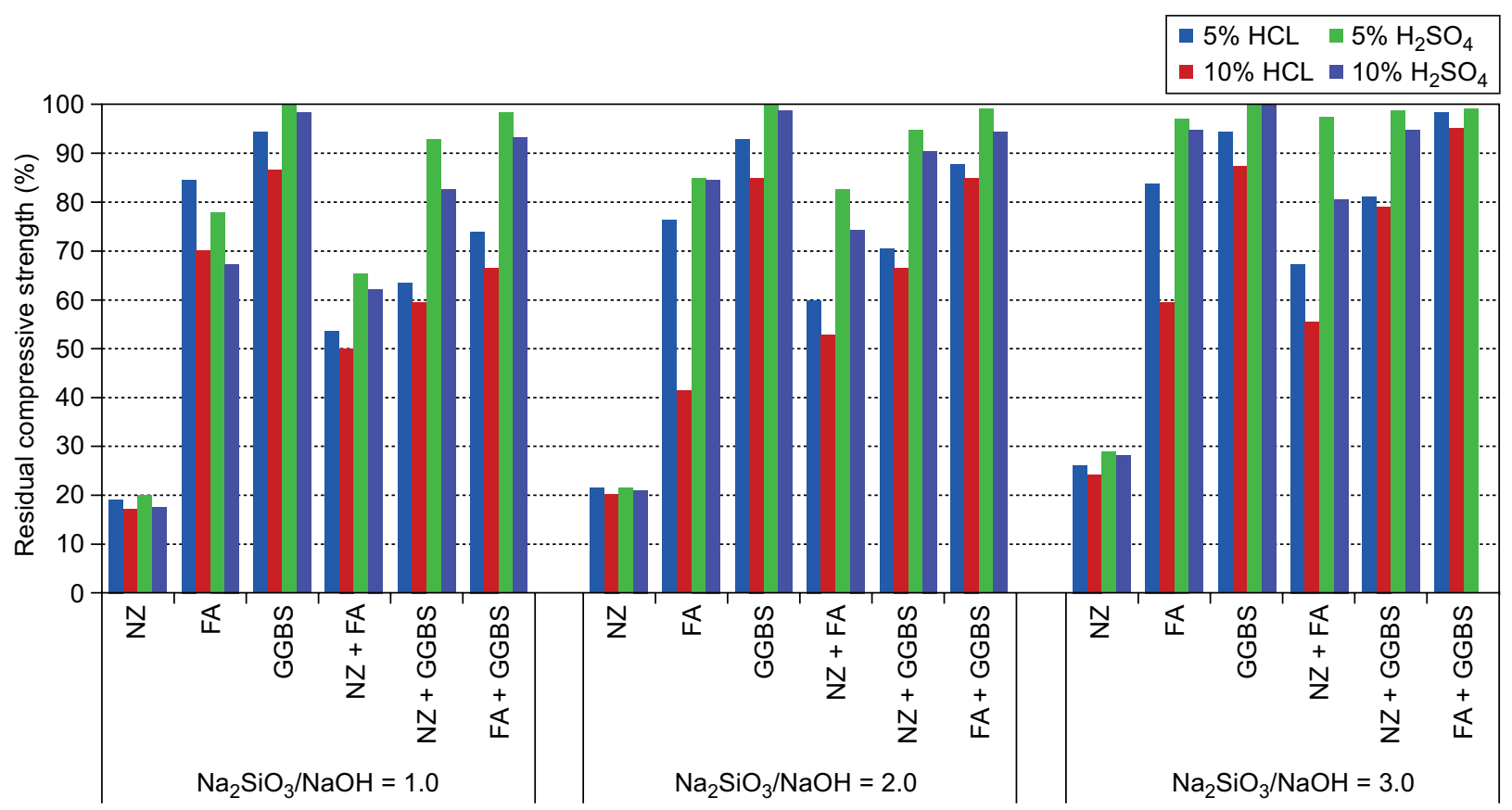

Figure 11. Effect of $\mathrm{Na}_{2} \mathrm{SiO}_{3} / \mathrm{NaOH}$ ratio in the alkaline solution on residual compressive strength of geopolymer mortars after 24 weeks exposure sulphate solutions.

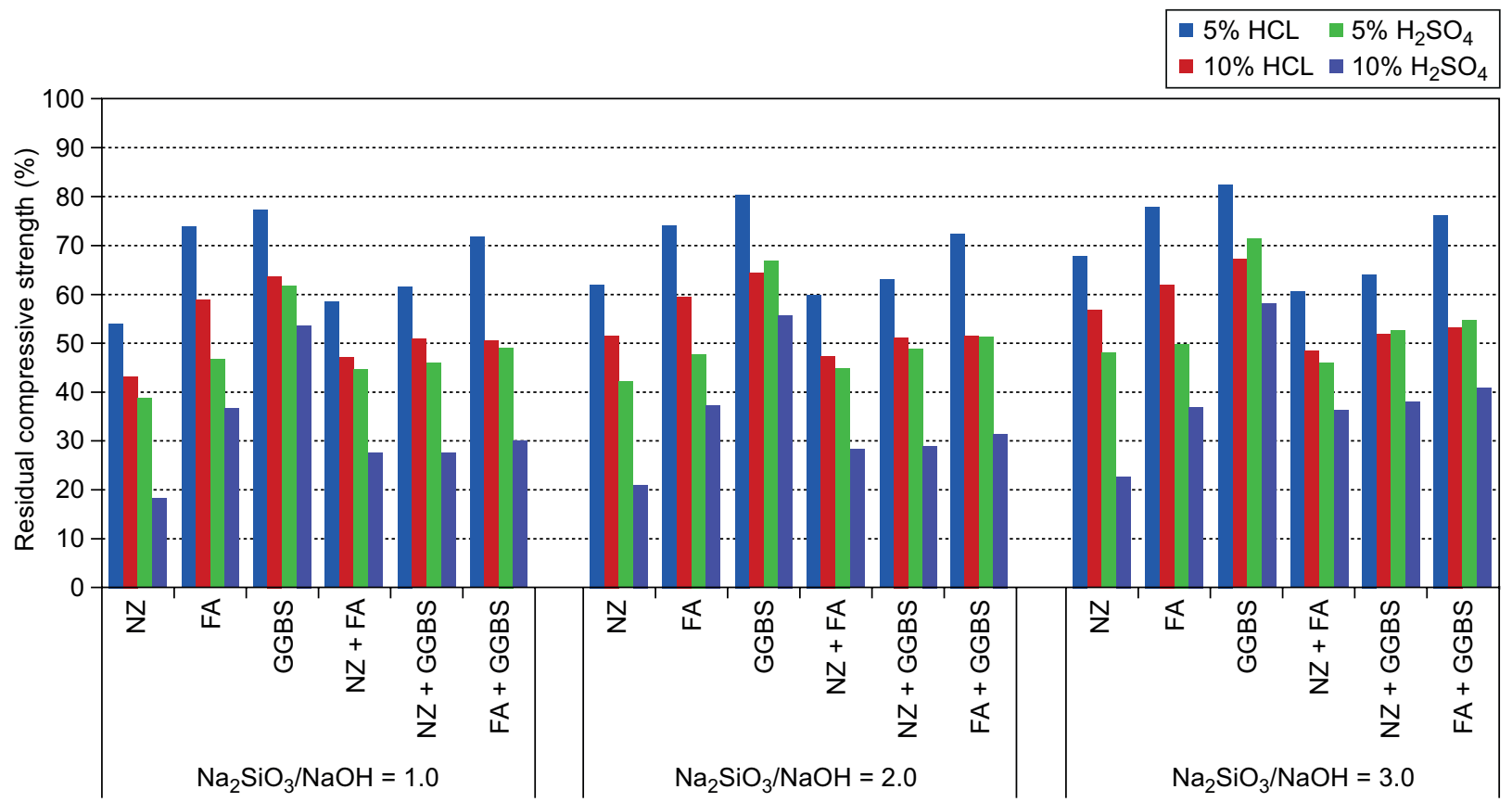

Figure 12. Effect of $\mathrm{Na}_{2} \mathrm{SiO}_{3} / \mathrm{NaOH}$ ratio in the alkaline solution on residual compressive strength of geopolymer mortars after 24 weeks exposure acid solutions. 
It has been observed that $\mathrm{Na}_{2} \mathrm{SiO}_{3} / \mathrm{NaOH}$ ratio is effective on residual compressive strength of geopolymer mortar in both sulphuric acid and hydrochloric acid exposure. Geopolymer mortar specimens prepared with different $\mathrm{Na}_{2} \mathrm{SiO}_{3} / \mathrm{NaOH}$ ratios showed varying degree of deterioration when exposed to sulphuric acid. The $\mathrm{Na}_{2} \mathrm{SiO}_{3} / \mathrm{NaOH}$ ratio increases as residual compressive strength increases. This increase is related to the dissolution of silicates and aluminates from the base materials. Basically, the increase in the $\mathrm{Na}_{2} \mathrm{SiO}_{3} /$ $/ \mathrm{NaOH}$ ratio was result in the increase of sodium content in the mixture. Sodium is important for the formation of geopolymers as it acts as charge balancing ions. The higher amount of sodium silicate improves the geopolymerisation when compared to sodium hydroxide content. The $\mathrm{Na}_{2} \mathrm{SiO}_{3} / \mathrm{NaOH}$ ratio, by weight, was recommended at approximately 2.5 for fly ash based geopolymers. Conversely, when the $\mathrm{Na}_{2} \mathrm{SiO}_{3} / \mathrm{NaOH}$ ratio was more than 3.0, the compressive strength tended to decrease due to the excessive alkali content which retards the geopolymerisation reaction [17]. Shankar and Khadiranaikar [27] observed that for the ratio of 2.5 the strength was maximum when compared with 3.5 in $10 \%$ sulphuric acid. Parthiban and Saravana [28] declared that the compressive strength of the geopolymer mixes increases with the increase in the alkaline ratio and the result with an alkaline ratio of 2 was found to be in the range of $21 \%$ to $25 \%$ than that of the mix with the alkaline ratio of 1.0. In this study, the highest residual compressive strength of geopolymer mortars was obtained when the $\mathrm{Na}_{2} \mathrm{SiO}_{3} / \mathrm{NaOH}$ ratio was 3.0, in both sodium sulphate and magnesium sulphate solution exposure. Test results showed that the compressive strength of geopolymer mortar increases when the amount of $\mathrm{Na}_{2} \mathrm{SiO}_{3}$ increases. The possible explanation of this increase may be connected to the use of more sodium silicate which led to more silica gel, and thus contributed to the high strength recorded at a $\mathrm{Na}_{2} \mathrm{SiO}_{3} /$ $/ \mathrm{NaOH}$ ratio of 3.0. GBBS was found to be more acid resistant, since the specimens even after 24 weeks of immersion in both $5 \%$ and $10 \%$ sulphuric acid and $5 \%$ and $10 \%$ hydrochloric acid solutions, remained almost intact. GGBS contains higher $\mathrm{CaO}$, and, as a result, it is a good potential base of soluble $\mathrm{Ca}$ in the mixture. The quantity of soluble $\mathrm{Ca}$ in the mixture has a direct effect on the compressive strength. FA and NZ contained much less $\mathrm{Ca}$ but when they were mixed with GGBS, the compressive strength of geopolymer mortar increased. Previous studies have shown that the addition of calcium has a positive effect on the mechanical properties of the geopolymeric binder [29]. But the exact role of calcium during the geopolymerization process is not fully understood. It was also declared by some researchers the addition of calcium from other bases to produce ambient cured geopolymer mortar improved its mechanical strength [30]. Meanwhile, some researchers claimed that the presence higher elements $\mathrm{CaO}$ causing disruption in the geopolymerization process [8]. It was observed that the effect of FA on compressive strength was more significant than the effect of NZ, which could be attributed to the higher pozzolanic activity of FA than that of NZ. NZ-based geopolymer may require thermal activation in order to obtain a geopolymer with good compressive strength properties [31]. GBBS gives quick hardening behavior to geopolymer mortar specimens. Higher calcium content may results in faster geopolymerisation due to the formation of semicrystalline $\mathrm{Ca}-\mathrm{Al}-\mathrm{Si}$ gel [32]. The GGBS mortar was permitted to stand at room temperature after mixing and just before being put into molds for a particular amount of time. The new geopolymer mortar is easily handled as much as 120 minutes without distortion in the shape of the specimens.

The most significant degradation was observed in the sodium sulphate solution rather than the magnesium sulphate solution. Bakharev [8] declared that this may be connected to a migration of alkalies into solution. The sulphuric and hydrochloric acid caused degradation in compressive strength, the extent of degradation depends on the type and concentration of acid solution and the period of exposure. It can be concluded that the sulphuric acid environment is more severe than the hydrochloric acid since the strength loss is more in sulphuric acid.

\section{CONCLUSIONS}

Geopolymer mortar specimens prepared with pozzolanic base materials with different $\mathrm{Na}_{2} \mathrm{SiO}_{3} / \mathrm{NaOH}$ ratios showed varying degree of deterioration when exposed to sulphuric acid. On the basis of findings during the present study, following conclusions are drawn.

- There is no damage to the surface of test specimens after exposure to sodium and magnesium sulphate solution up to 24 weeks. The visual appearance of geopolymer specimens after $5 \%$ and $10 \%$ sulphuric acid immersion showed that acid attack slightly damaged the surface of specimens. The best performance in different sulphate and acid solutions was observed in the geopolymer mortar prepared GGBS cured at ambient temperatures. It was observed that the surface of the NZ specimens exposed to $10 \%$ sulphuric acid was badly defeated and the aggregates were clearly visible.

- Geopolymer mortar specimens gained weight during exposure to sodium and magnesium sulphate solutions. Maximum increase in weight was observed in $\mathrm{NZ}$ specimens and least gain in weight occurred in GGBS specimens. The pattern of weight gain is almost similar for three different $\mathrm{Na}_{2} \mathrm{SiO}_{3} / \mathrm{NaOH}$ ratios.

- The weight loss was observed to be gradually decreased with increase in $\mathrm{Na}_{2} \mathrm{SiO}_{3} / \mathrm{NaOH}$ ratio for all the specimens immersed in sulphuric and hydrochloric 
acid. The maximum weight loss was obtained for NZ based geopolymer mortar specimens in $10 \%$ sulphuric and hydrochloric acid solutions after 24 weeks.

- GGBS based geopolymer mortar was found to possess much higher sulphate and acid resistance when measured in terms of loss of weight and the residual compressive strength. NZ based geopolymer showed very weak performance in acidic medium, in both weight changes and strength degradation. FAbased geopolymer samples had moderate residual compressive strength in both sulphate and acid solutions

- The inclusion of FA in the GGBS based geopolymer mixture is found to be a suitable base of geopolymer mortar under ambient curing conditions.

- It has been observed that the $\mathrm{Na}_{2} \mathrm{SiO}_{3} / \mathrm{NaOH}$ ratio is effective on residual compressive strength of geopolymer mortar in both sulphuric acid and hydrochloric acid exposure. The higher ratio of $\mathrm{Na}_{2} \mathrm{SiO}_{3} / \mathrm{NaOH}$ results in a higher residual compressive strength.

- The most significant degradation was observed in the sodium sulphate solution rather than the magnesium sulphate solution.

- The sulphuric acid environment is more severe than the hydrochloric acid since the strength loss was more in sulphuric acid.

- When compared to acid and sulphate immersion, acid was found to be aggressive indicating higher weight and strength loss.

- Exposure to acid caused degradation in the compressive strength, the extent of degradation was related to the type of acid, concentration and period of exposure.

Finally, the information presented in this research will be beneficial in the design of geopolymer mortar at ambient curing conditions in order to enhance the durability of geopolymer mortar and, in particular, to enhance its mechanical properties. The mixture of two or more raw materials could also be used for strength requirement. Furthermore, as an alternative material of cement, the consumption of FA and GGBS in the presence of alkali solution would be a probable and sustainable solution to reduce the demand of cement which also helps to achieve the goal of sustainable concrete.

\section{Acknowledgments}

The work reported in this paper is a part of the investigation within the research project BAP.2016.0001 "Durability Properties of Geopolymer Mortar Containing Pozzolanic Waste Materials" supported by the Balikesir University, Turkey.

\section{REFERENCES}

1. Neville A. M. (2000). Properties of Concrete. $4^{\text {th }}$ ed. Pearson education, Longman group.

2. Davidovits J., Comrie D.C., Paterson J.H., Ritcey D.J. (1990): Geopolymeric concretes for environmental protection. ACI Concrete International, 12, 30-40.

3. Arioz E., Arioz O., Koçkar O.M. (2013): Mechanical and microstructural properties of fly Ash based geopolymers. International Journal of Chemical Engineering and Applications, 4(6), 397-400. doi: 10.7763/IJCEA.2013.V4.333

4. Hardjito D., Wallah S. E., Sumajouw D. M. J., Rangan B. V. (2004): On the Development of Fly Ash-Based Geopolymer Concrete. ACI Materials Journal, 101(6), 467-472.

5. Nath P., Sarker P.K. (2014): Effect of GGBFS on setting, workability and early strength properties of fly ash geopolymer concrete cured in ambient condition. Construction and Building Materials, 66, 163-171. doi:10.1016/j. conbuildmat.2014.05.080

6. Wallah S.E., Rangan B. V. (2006). Low calcium fly ash based geopolymer concrete: Long term properties, Research report GC2, Curtin University of Technology, Australia

7. Bascarevic Z., Komljenovic M., Miladinovic Z., Nikolic V., Marjanovic N., Petrovic R. (2015): Impact of sodium sulphate solution on mechanical properties and structure of fly ash based geopolymers. Materials Structures, 48(3), 683-697. doi: 10.1617/s11527-014-0325-4

8. Bakharev T. (2005): Durability of geopolymer materials in sodium and magnesium sulphate solutions. Cement and Concrete Research. 35(6), 1233-1246. doi:10.1016/j. cemconres.2004.09

9. Bakharev T. (2005): Resistance of geopolymer materials to acid attack. Cement and Concrete Research. 35(4), 658-670. doi:10.1016/j.cemconres.2004.06.005

10. Davidovits J. (1994): Global warming impact on the cement and aggregates industries. World Resource Review, 6(2), 263-278.

11. MustafaAl Bakri A.M., Kamarudin H, Bnhussain M., Khairul Nizar I, Rafiza A. R., Zarina Y. (2012): The processing, characterization, and properties of fly ash based geopolymer concrete. Reviews on Advanced Materials Science, 30 (1), 90-97.

12. Van Deventer J.S.J., Provis J.L., Duxson P., Lukey G.C. (2007): Reaction mechanisms in the geopolymeric conversion of inorganic waste to useful products. Journal of Hazardous Materials, 13 (3), 506-513. doi:10.1016/j. jhazmat.2006.02.044

13. Arioz E., Arioz Ö., Koçkar O.M. (2013): The effect of curing conditions on the properties of geopolymer samples. International Journal of Chemical Engineering and Applications, 4 (6), 423-426.

14. Faris M.A., MustafaAl Bakri A., Sandu V.A., Khairul Nizar I., Moga L.M., Necula O., Muniandy R. (2017): Assessment of alkali activated geopolymer bases as an alternative of Portlant cement. Materiale Plastice, 54(1), 145-154.

15. Elibol C., Sengul O. (2016): Effects of activator properties and ferrochrome slag aggregates on the properties of alkaliactivated bast furnace slag mortars. Arabian Journal for Science and Engineering, 41 (4), 1561-1571. doi: 10.1007/ s13369-015-1910-8

16. Mustafa Al Bakri A.M., Kamarudin H, Bnhussain M., Rafiza A. R., Zarina Y. (2012): Effect of $\mathrm{Na}_{2} \mathrm{SiO}_{3} / \mathrm{NaOH}$ 
ratios and $\mathrm{NaOH}$ molarities on compressive strength of fly-ash-based geopolymer. ACI Materials Journal, 109(5), 503-508.

17. Hardjito D., Rangan B.V. (2005). Development and properties of low-calcium fly ash-based geopolymer concrete. Research Report. GCI, Faculty of Engineering, Curtin University of Technology, Australia.

18. Pacheco-Torgal F., Castro-Gomes J., Jalali S. (2008): Alkali-activated bases: A review. Part 2. About materials and bases manufacture. Construction and Building Materials, 22 (2008) 1315-1322. doi:10.1016/j.conbuildmat. 2007.03.019.

19. Thokchom S., Ghosh P., Ghosh S. (2010): Performance of fy ash based geopolymer mortars in sulphate solution. Journal of Engineering Science and Technology Review, 3(1), 36-40.

20. Turkish Standard Institute-TS EN 196-1 (2009). Methods of testing cement-Part 1: Determination of strength. TSI, Ankara.

21. ASTM Standard C618-94a (1994). Standard specification for coal fly ash and raw or calcined natural pozzolan for use as a mineral admixture in Portland Cement concrete. Annual Book of ASTM Standards, Vol. 04.02. ASTM, Philadelphia.

22. Turkish Standard Institute-TS (2006). EN 15167-1, Ground granulated blast furnace slag for use in concrete, mortar and grout-Part 1: definitions, specifications and conformity criteria. TSI, Ankara.

23. ASTM Standard C230M-14 (2014). Standard specification for flow table for use in tests of hydraulic cement. American Society for Testing and Materials, Philadelphia.

24. ASTM Standard C 267-1 (2012). Standard test methods for chemical resistance of mortars, grouts, and monolithic surfacings and polymer concretes. American Society for Testing and Materials, Philadelphia.
25. Bhutta M.A.R, Ariffin N.F., Hussin M.W., Nor Hasanah A.S.L. (2013): Sulphate and sulphuric acid resistance of geopolymer mortars using waste blended ash. Jurnal Teknologi, 61, 3, 1-5. doi: 10.11113/jt.v61.1762

26. Pacheco-Torgal F., Jalali S. (2010): Influence of sodium carbonate addition on the thermal reactivity of tungsten mine waste mud based bases. Construction and Building Materials, 24(1), 56-60. doi: 10.1016/j.conbuildmat.2009. 08.018

27. Sanni S.H., Khadiranaikar, R. B. (2012): Performance of geopolymer concrete under severe environmental conditions. International Journal of Civil and Structural Engineering, 3(2), 396-407.

28. Parthiban K., Saravana R.M.K. (2014): Effect of sodium hydroxide concentration and alkaline ratio on the compressive strength of slag based geopolymer concrete. International Journal of ChemTech Research, 6(4), 2446-2450.

29. Yip C.K., Van Deventer J.S.J. (2001): Effect of granulated blast furnace slag on geopolymerisation, in: Proceedings of 6th World Congress of Chemical Engineering, Melbourne, Australia.

30. Van Jaarsveld J. G. S., Van Deventer J. S. J., Schwartzman, A. (1999): The potential use of geopolymeric materials to immobilise toxic metals: Part II. Material and leaching characteristics. Mineral. Engineering, 12(1), 75-91. doi:10. 1016/S0892-6875(98) 00121-6

31. Khater H.M. (2012): Effect of calcium on geopolymer ization of aluminosilicates wastes. ASCEJournal Materials Civil Engineering, 24(1), 92-101. doi:10.1061/(ASCE) MT.1943-5533.0000352

32. Lee W.K.W., Van Deventer J.S.J. (2002): The effects of inorganic salt contamination on the strength and durability of geopolymers. Colloids and Surfaces A: Physicochemical and Engineering Aspects, 211(2-3), 115-126. doi:10.1016/ S0927-7757(02)00 